\title{
International Environmental Law for the 21st Century: The Constitutionalization of the Right to a Healthy Environment in the Inter-American Court of Human Rights Advisory Opinion No. 23
}

Fecha de recepción: 5 de febrero de 2018

Fecha de aceptación: 6 de julio de 2018

Doi: dx.doi.org/10.12804/revistas.urosario.edu.co/acdi/a.7568

\author{
Monica Feria-Tinta \\ Simon C. Milnes*
}

Abstract: This article analyses the recent Advisory Opinion of the InterAmerican Court of Human Rights on Environment and Human Rights and argues that it constitutes a milestone effectively reorientating international environmental law. The article is divided as follows. First, it analyses the most salient aspects of the Advisory Opinion inter alia (1) The right to a bealtby environment as binding law and; (2) The Advisory Opinion as a landmark in the gradual development of international jurisprudence on

* The authors are barristers (advocates), members of the English Bar who practise at 20 Essex Street Chambers, 20 Essex Street, London, WC2R 3AL, United Kingdom (mferia-tinta@20essexst.com; smilnes@20essexst.com). Mr Milnes wishes to thank and acknowledge Santiago Díaz-Cediel and Ignacio F. Grazioso for a long interchange of ideas in the course of preparing an amicus curiae brief and oral submissions to the InterAmerican Court of Human Rights on its recent advisory opinion discussed below, under the auspices of the Georgetown University Human Rights Institute.

Para citar este artículo: Feria-Tinta, M. \& Milnes, S. C., "International Environmental Law for the 21st Century: The Constitutionalization of the Right to a Healthy Environment in the Inter-American Court of Human Rights Advisory Opinion No. 23", Anuario Colombiano de Derecho Internacional (ACDI), 2019, 12, pp. 43-84. Doi: dx.doi.org/10.12804/revistas.urosario.edu.co/acdi/a.7568 
cross-border (or "diagonal") human rights obligations (i.e. the possibility for human rights claims to be brought by individuals not under the territorial jurisdiction of the State whose international responsibility for environmental harm is invoked). Second, it contextualizes the Advisory Opinion by discussing what we consider to be four key vectors currently affecting the trajectory of the ongoing development of international environmental law and how the advances made in the Advisory Opinion fit with those developments. Third, it places the Advisory Opinion in the wider context of developments moving towards a needed reorientation in international environmental law, in particular: integration (or de-fragmentation) of international law, the operationalization of environmental principles into working-level legal norms, and a focus on practical remedies. It is argued that as the world experiences the pressure for more effective environmental law and accountability, some of the most sophisticated and innovative thinking on international environmental law today, is emanating from countries in the Southern hemisphere, as attested to by the Advisory Opinion.

Keywords: Environmental law, diagonal obligations, remedies, Right to a healthy environment, Advisory Opinion 23, Inter-American Court of Human Rights, International Dispute Resolution, investment law, defragmentation of international law.

International Environmental Law for the 21st Century: The Constitutionalization of the Right to a Healthy Environment in the Inter-American Court of Human Rights Advisory Opinion No. 23

Resumen: este artículo analiza la reciente Opinión Consultiva de la Corte Interamericana de Derechos Humanos sobre el Medio Ambiente y los Derechos Humanos y sostiene que constituye un hito que reorienta efectivamente el derecho ambiental internacional. El artículo está dividido como sigue: En primer lugar, analiza los aspectos más destacados de la Opinión Consultiva, entre otros (1) El derecho a un medio ambiente sano como derecho vinculante; (2) La Opinión Consultiva como un hito en el desarrollo gradual de la jurisprudencia internacional sobre las obligaciones de derechos humanos transfronterizas (o "diagonales") (es decir, la posibilidad de que los individuos que no están bajo la jurisdicción territorial del Estado presentendemandas de derechos humanos cuya responsabilidad 
internacional por daños ambientales se invoca). En segundo lugar, el artículo contextualiza la Opinión Consultiva al analizar lo que consideramos cuatro vectores claves que afectan actualmente la trayectoria del desarrollo en curso del derecho ambiental internacional, y cómo los avances logrados en la Opinión Consultiva encajan con esos desarrollos. En tercer lugar, coloca la Opinión Consultiva en el contexto más amplio de los desarrollos que se dirigen hacia una reorientación necesaria en el derecho ambiental internacional, en particular: la integración (o des-fragmentación) del derecho internacional, la operacionalización de los principios ambientales en las normas legales a nivel práctico y un enfoque en remedios. Se argumenta que en tanto que el mundo experimenta la presión por normas de derecho medioambiental más efectivas y con consecuencias legales si son violadas, ejemplos de pensamientos más sofisticados e innovadores en materia de derecho del medio ambiente actual, vienen emanando de los países del hemisferio sur, como lo confirma la Opinión Consultiva.

Palabras clave: derecho del medioambiente, derecho a un ambiente sano, obligaciones diagonales, Opinión Consultiva 23, Corte Inter-Americana de Derechos Humanos, Resolución de Conflictos Internacionales, derecho de inversión, de-fragmentación del derecho internacional.

Direito ambiental internacional para o século XXI: a constitucionalização do direito a um meio ambiente saudável na Corte Interamericana de Direitos Humanos Opinião Consultiva número 23

Resumo: este artigo analisa a recente Opinião Consultiva da Corte Interamericana de Direitos Humanos sobre o Meio Ambiente e os Direitos Humanos e sustenta que constitui um marco que reorienta efetivamente o direito ambiental internacional. $\mathrm{O}$ artigo está dividido como segue: em primeiro lugar, analisa os aspectos mais destacados da Opinião Consultiva, entre outros (1) O direito a um meio ambiente saudável como direito vinculante; (2) A opinião Consultiva como um marco no desenvolvimento gradual da jurisprudência internacional sobre as obrigações de direitos humanos transnacionais (ou "diagonais") (é dizer, a possibilidade de que os indivíduos que não estejam sob a jurisdição territorial do Estado apresente demandas de direitos humanos cuja responsabilidade internacional por danos ambientais invoca-se). Em segundo lugar, o artigo contextualiza a 
Opinião Consultiva ao analisar o que consideramos quatro vetores chave que afetam atualmente a trajetória do desenvolvimento em curso do direito ambiental internacional, e como os avanços logrados na Opinião Consultiva encaixam com esses desenvolvimentos. Em terceiro lugar, põe à Opinião Consultiva no contexto mais amplo dos desenvolvimentos que se dirigem à uma reorientação necessária no direito ambiental internacional, em particular: a integração (ou desfragmentação) do direito internacional, a operacionalização dos princípios ambientais nas normas legais no nível prático e um foco em remédios. Se argumenta que enquanto o mundo experimenta a pressão por normas de direito meio ambiental mais efetivas e com consequências legais se são violadas, exemplos de pensamentos mais sofisticados e inovadores em matéria de direito do meio ambiente atual, vêm emanando dos países do hemisfério sul, como o confirma a Opinião Consultiva.

Palavras-chave: direito do meio ambiente, direito a um ambiente saudável, obrigações diagonais, Opinião Consultiva 23, Corte Interamericana de Direitos Humanos, Resolução de Conflitos Internacionais, direito de investimento, desfragmentação do direito internacional.

In its collective dimension, the right to a healthy environment constitutes a universal interest, which is owed both to present and future generations. [...] The degradation of the environment can cause irreparable damage to buman beings, and therefore a bealthy environment is a fundamental right for the existence of bumanity. ${ }^{1}$

1 Inter-Am. Ct. H. R., The environment and buman rights — State obligations in relation to the environment in the context of the protection and guarantee of the rights to life and to personal integrity - Interpretation and scope of articles 4(1) and 5(1) of the American Convention on Human Rights-, Advisory Opinion OC-23/18, (ser. A), No 23, 15 November 2017 (available in Spanish only), \59. M Feria-Tinta's translation.

In the original Spanish: "En su dimensión colectiva, el derecho a un medio ambiente sano constituye un interés universal, que se debe tanto a las generaciones presentes y futuras. [...] La degradación del medio ambiente puede causar daños irreparables en los seres humanos, por lo cual un medio ambiente sano es un derecho fundamental para la existencia de la humanidad". 


\section{Introduction}

Ecological systems are severely degraded, to the point where some scientists foresee a possible 'planetary collapse' within our lifetimes. ${ }^{2}$ That very fact is a harsh verdict on the insufficiency of international environmental law as it has developed from its emergence in the 1970s to the present. Do legal tools exist that could suffice to assure our survival?

Increasingly, international and domestic courts and tribunals are confronting that question, and in some cases taking innovative steps to forge such tools. The Republic of Colombia has been, in more ways than one, a key actor in these global developments. The Supreme Court cases concerning the Atrato River and the Amazon, ${ }^{3}$ in addition to their intrinsic value in preserving ecological resources of inestimable worth, also offer a model which may enrich and influence judicial developments in other countries. Moreover, it was Colombia which submitted a Request to the Inter-American Court of Human Rights (IACtHR) which led to the publication on 7 February 2018 of this Court's ground-breaking Advisory Opinion on the Environment and Human Rights, ${ }^{4}$ perhaps the most significant ruling on environmental issues of any international tribunal to date.

This article aims to situate current developments within the wider problematique of human and ecological survival, the quest for an international law that possesses real utility in tackling the crisis which confronts humankind. The article is divided into four parts. Part I analyses the most salient aspects of the Advisory Opinion. Part II contextualizes the Advisory Opinion by discussing what we consider to be four key vectors currently affecting the trajectory of international environmental law's ongoing development, and how the advances made in the Advisory Opinion fit with those developments. Part III outlines a prescription for an urgently needed reorientation in international environmental law, advocating in particular: integration (or de-fragmentation) of international law, the operationalization of environmental principles into working-level legal norms, and a focus on practical remedies. In the effort to reorient international environmental law,

2 E. g., Barnosky, A. D. et al., "Approaching a State shift in Earth's biosphere", Nature, January 2012; Ahmed, N., "Nasa-funded study: industrial civilisation headed for 'irreversible collapse?", The Guardian, 14 March 2014.

3 These cases are discussed briefly below: see the text accompanying n. 51-53, infra.

4 Inter-Am. Ct. H.R., The environment and human rights, op. cit., n. 2, supra. 
the Advisory Opinion is likely to prove a milestone: in particular, it has illuminated the many powerful ways in which the environmental dimension of human rights has binding constitutional force under the American Convention on Human Rights. ${ }^{5}$ Part IV concludes.

\section{The Advisory Opinion of the Inter-American Court of Human Rights on the Environment and Human Rights}

\section{A. Colombia's Request to the IACtHR for an Advisory Opinion}

In March 2016, Colombia, submitted a Request to the IACtHR, ${ }^{6}$ asking three main questions, namely (as a précis):

(1) If an individual living in Country A suffers a human rights violation caused by environmental damage emanating from Country B, can that individual bring a claim to hold Country $\mathrm{B}$ responsible under the American Convention on Human Rights ${ }^{7}$ (American Convention)?

(2) Would Country B breach the American Convention if — by act or omission- it were to cause serious transboundary environmental damage that undermined the rights to life and personal integrity (protected by Articles 4 and 5 of the American Convention) of people living in Country A?

(3) Does the American Convention require Country B to comply with the norms of international environmental law, and does that include, as one necessary mode of compliance, a requirement to carry out an environmental impact assessment of proposed

\footnotetext{
5 OAS Treaty Series, No 36, 1144 UnTS 123, entered into force 18 July 1978.

6 "Request for an advisory opinion, presented by the Republic of Colombia, concerning the interpretation of article 1(1), 4(1) and 5(1) of the American Convention on Human Rights", 14 March 2016, in http://www.corteidh.or.cr/solicitudoc/solicitud_14_03_16_ing. pdf, accessed on 10 April 2018.

7 American Convention on Human Rights (Pact of San José), adopted at San José, Costa Rica, on 22 November 1969, entered into force 18 July 1978, OAS Treaty Series, No 36.
} 
projects with potential transboundary impacts? And if so, what does that obligation generally entail? ${ }^{8}$

Colombia's Request elicited a detailed and carefully reasoned ruling. The Advisory Opinion is the first legal pronouncement ever made by an international human rights court with a true focus on environmental law as a systemic whole. ${ }^{9}$ It also unequivocally places environmental rights in the sphere of basic rights that are justiciable under the American Convention. This matters because, as the UN Special Rapporteur on human rights and the environment, Professor John Knox, observed "[ $t]$ he drafters of the seminal human rights instrument, the 1948 Universal Declaration of Human Rights did not include environmental rights". ${ }^{10}$ Yet, as the IACtHR noted, without a healthy environment other human rights are often nullified. ${ }^{11}$ The lack of an overt mention of environmental rights as basic rights in the Universal Declaration — and indeed the American Convention - is remedied by the IACtHR's conclusion.

Colombia's Request represented an intricate intermingling of political and environmental concerns. Its backdrop and impetus were the ongoing disputes with Nicaragua over maritime boundaries, ${ }^{12}$ and the threat posed by potentially unbridled infrastructure development in Nicaragua to the vulnerable ecosystems and means of livelihood in Colombia's maritime

8 Feria-Tinta, M. \& Milnes, S. C., "The rise of environmental law in international dispute resolution: the Inter-American Court of Human Rights issues a landmark advisory opinion on environment and human rights", Yearbook of International Environmental Law, 2018, 27 (forthcoming).

9 Feria-Tinta, M. \& Milnes, S. C., "The rise of environmental law in international dispute resolution: Inter-American Court of Human Rights issues a landmark advisory opinion on environment and human rights”, EJIL Talk!, Blog, 26 February 2018.

10 Human Rights Council, Preliminary report of the independent expert on the issue of human rights obligations relating to the enjoyment of a safe, clean, bealthy and sustainable environment, John H. Knox, 24 December 2012, un Doc. A/HRC/22/43, \$ 7.

11 Advisory Opinion, $\ 59$.

12 The International Court of Justice had decided a dispute on maritime boundaries between Colombia and Nicaragua adversely to Colombia. Territorial and maritime dispute (Nicaragua v Colombia), Judgment, ICJ Reports, 2012, p. 624. Following this, Colombia had withdrawn its optional clause declaration under Article 36(2) of the ICJ Statute. As a consequence, Colombia would no longer have a right of recourse to the ICJ against Nicaragua, for example in cases of environmental harm. 
provinces. ${ }^{13}$ In particular, plans by Nicaragua to build, with funding from China, a 170-mile rival to the Panama Canal linking the Caribbean Sea and the Pacific Ocean, dubbed "the biggest earth-moving operation in history", ${ }^{14}$ are considered by scientists to threaten irreversible harm to the marine ecosystem in Caribbean waters. It is feared that this megaproject would destroy the marine ecosystem in the area (killing reefs, seagrass and fish), followed by chemical pollution and bringing invasive species introduced by shipping lane bottlenecks. ${ }^{15} \mathrm{~A}$ case pending, at admissibility level, before the Inter-American Commission on Human Rights brought by indigenous populations against Nicaragua in relation to the construction of the canal, was likewise in the background. ${ }^{16}$ Colombia's Request thus brought under the Court's purview a compelling contemporary issue: the ability (or lack thereof) of international law to regulate unrestrained development of infrastructure megaprojects, not least given the transboundary harms they may cause. As Colombia's Request noted, we are indeed "living at a time when major infrastructure projects are frequently being built and brought into operation $[\ldots]$ with effects that may exceed state boundaries". ${ }^{17}$

Despite this specific context, the Request raised issues that transcended any particular bilateral dispute. Colombia's Request led to a fertile debate before the IACtHR, with carefully deliberated interventions by states

13 This political 'edge' to the Request would doubtless have been apparent to the IACtHR, and in any event, the Guatemalan representative at the hearing on Colombia's Request drew attention to the need to ensure that any Advisory Opinion did not undermine the ICJ's settlement of that territorial dispute. Feria-Tinta, M. \& Milnes, S. C. n. 9, supra. The IACtHR deftly defused that aspect by concentrating on the issues of principle and avoiding expressing any concrete views on particular instances of pollution sources or their victims. $I d$.

14 Gibbs, S. \& Elliott, L., "China puts Nicaraguan canal plan on hold", The Times, 19 June 2017.

15 Feria-Tinta, M. \& Milnes, S. C., "How international law could help victims of environmental degradation", The Guardian, 21 February 2018.

16 Petition 912/14 filed before the Inter-American Commission on Human Rights on 17 June 2014. See Advisory Opinion at para. 25. For further information on the petition see FIDH report "Concesión del canal interoceánico en Nicaragua: grave impacto en los derechos humanos - Comunidades campesinas movilizadas resisten", September $2016 \mathrm{~N}^{\circ}$ 680e, in https://www.fidh.org/IMG/pdf/nicaragua680esp2016web-1gg.pdf, accessed on 31 July 2018.

17 Request at para. 9. 
parties to the American Convention, ${ }^{18}$ intergovernmental organisations, ${ }^{19}$ and civil society organisations. ${ }^{20}$ A notable feature of the submissions by regional states was the consistent support for recognition of environmental rights, broadly in favour of an affirmative answer to the questions posed in Colombia's Request. ${ }^{21}$

In turn, the IACtHR's response to Colombia's three questions was also broadly in the affirmative, in certain respects even more so than the Request had envisaged. ${ }^{22}$ We have discussed some central aspects of the IACtHR's ruling elsewhere. ${ }^{23}$ Below we offer a brief account of the most salient features of the Advisory Opinion, as a preliminary to situating the

18 Argentina, Bolivia, Honduras and Panama made written observations and intervened orally before the Court. Guatemala intervened orally at the hearings. Advisory Opinion op. cit., at para. 6 and 9.

19 The Inter-American Commission on Human Rights, the General Secretariat from the Organisation of American States (OAS) with the International Union for Conservation of Nature's World Commission on Environmental Law, and the International Maritime Organisation. Id.

20 There were forty four interventions from civil society.

21 See Feria-Tinta, M. \& Milnes, S. C., n. 9, supra. One State, Panamá, expressed more restrictive views but nonetheless emphasized the importance of states adhering to international environmental norms). Guatemala and Honduras favoured Colombia's position, while Bolivia (which did not submit any written observations) made oral submissions going even further, in line with the Bolivian government's strongly environmentalist and indigenous peoples-oriented stance. Argentina advocated for a more cautious and contextdriven approach, but one that was open to "diagonal" jurisdiction based on concrete facts (similar to the IACtHR's eventual ruling).

22 On the first question, the IACtHR adopted a broader approach than Colombia had proposed, in that it declined Colombia's invitation to base either substantive state human rights obligations or the scope of "jurisdiction" under Article 1(1) of the American Convention on the existence or otherwise of any other treaty regime such as the Convention for the Protection and Development of the Marine Environment of the Wider Caribbean Region, adopted in Cartagena, Colombia, 24 March 1983, entered into force 11 October 1986 (Cartagena Convention).

23 Some key aspects of the decision have been briefly discussed in Feria-Tinta, M. \& Milnes, S. C., "How international law could help victims of environmental degradation", The Guardian, 21 February 2018; and Feria-Tinta, M. \& Milnes, S. C., "The rise of environmental law in international dispute resolution: Inter-American Court of Human Rights issues a landmark advisory opinion on environment and human rights", EJIL Talk!, Blog, 26 February 2018. For an in-depth analysis of aspects of the Advisory Opinion, see Feria-Tinta, M. \& Milnes, S. C., "The rise of environmental law in international dispute resolution: the Inter-American Court of Human Rights issues a landmark advisory opinion 
Advisory Opinion within the broader arc of international environmental law (Part II).

\section{B. Salient Aspects of the Advisory Opinion}

In our view, the most salient aspects of the Advisory Opinion can be described as:

(1) The substantive aspect: The IACtHR recognised the basic right to a healthy environment under the American Convention;

(2) The jurisdictional aspect: The Advisory Opinion opens the door —albeit in a cautious and pragmatic way - to diagonal human rights claims, and this has potential to unlock real remedies for the victims of transboundary environmental pollution; ${ }^{24}$

(3) Due diligence and procedural obligations (and rights) are given a central role as organizing principles for state conduct; and

(4) More adventurously yet, the Court recognizes the evolving trend of assigning the status of a rights-bearer to the environment itself, or components of it.

These aspects are discussed in a little more detail below.

\section{(1) The Substantive Aspect - The Right to a Healthy Environment}

While an emphasis on the importance of natural resources and the environment has already featured prominently in the jurisprudence arising from claims brought by indigenous and tribal populations, ${ }^{25}$ the Advisory

on environment and human rights", Yearbook of International Environmental Law, 2018, 27 (forthcoming).

24 Id.

25 A critical link between human beings' subsistence and the environment has already been noted by earlier Inter-American Commission's reports, e. g., IACHR, "Indigenous and tribal people's rights over their ancestral lands and natural resources, norms and jurisprudence of the Inter-American Human Rights System", 30 December 2009. OEA/Ser.I/L/V/II. Doc. 56/09, $\$ 192$, in http://www.oas.org/en/iachr/indigenous/docs/pdf/ancestrallands.pdf, accessed on 20 April 2018. The Inter-American Commission on Human Rights —aptly quoted by the Advisory Opinion - has pointed out in the past that "several fundamental rights require, as a necessary precondition for their enjoyment, a minimum environmental 
Opinion breaks new ground in analysing individual rights in relation to the environment, in a central and systematic manner. ${ }^{26}$ The Court recognized the right to a healthy environment, in its individual and collective dimensions, ${ }^{27}$ as a fundamental right for the existence of humanity. ${ }^{28}$ While the American Convention itself does not explicitly provide for such a right, the Court interpreted the American Convention as a living instrument, taking an evolutive and systemic interpretative approach. ${ }^{29}$ Article 11 of the Protocol of San Salvador ${ }^{30}$ to the American Convention does provide expressly for the right to a healthy environment, and the Preamble to the Protocol of San Salvador acknowledges the close relationship that exists between economic, social and cultural rights (which include the right to a healthy environment) and civil and political rights, "in that the different categories of rights constitute an indivisible whole based on the recognition of the dignity of the human person". ${ }^{31}$ The Commission has also held in the context of its reporting functions that "where environmental contamination and degradation pose a persistent threat to human life and health, the foregoing rights are implicated". 32 The Advisory Opinion likewise held

quality, and are profoundly affected by the degradation of natural resources". See Advisory Opinion, para. 48 citing the IACHR, "Indigenous and tribal people's rights over their ancestral lands and natural resources, norms and jurisprudence of the Inter-American Human Rights System", 30 December 2009. OEA/Ser.I/L/V/II. Doc. 56/09, at para. 190, in http:/ /www. oas.org/en/iachr/indigenous/docs/pdf/ancestrallands.pdf, accessed on 20 April 2018.

26 Feria-Tinta, M. \& Milnes, S. C., "The rise of environmental law in international dispute resolution: the Inter-American Court of Human Rights issues a landmark advisory opinion on environment and human rights", Yearbook of International Environmental Law, 2018, 27 (forthcoming).

27 Advisory Opinion, para. 47.

28 Advisory Opinion, para. 59.

29 See Advisory Opinion, $\$ 43, \$ 44$.

30 Additional Protocol to the American Convention on Human Rights in the Area of Economic, Social and Cultural Rights, Signed at San Salvador, El Salvador, on November 17, 1988, at the eighteenth regular session of the General Assembly of the OAS. OAS Treaty Series, $\mathrm{N}^{\circ}$ 69. Basic documents pertaining to human rights in the Inter-American System, OEA/Ser. I./V.I.4 rev 8, 22 May 2001. Article 11 provides: "(Right to a Healthy Environment) 1. Everyone shall have the right to live in a healthy environment and to have access to basic public services. 2. The State Parties shall promote the protection, preservation and improvement of the environment".

31 Protocol of San Salvador, Preamble, recital 3, cited in Advisory Opinion, $\$ 47$.

32 IACHR, Report on the situation of human rights in Ecuador. Doc OE/Ser.L/V/II.96, Doc. 
that "environmental degradation [...] affects the effective enjoyment of human rights". ${ }^{33}$ It acknowledged the interdependence and indivisibility between human rights and the protection of the environment, giving rise to state obligations. ${ }^{34}$ The environmental obligations become stricter if, in addition to a human rights treaty, there is also an environmental treaty (such as the Cartagena Convention). ${ }^{35,36}$

\section{(2) 'Diagonal' Human Rights Obligations}

The Advisory Opinion is likely to prove a landmark in the gradual development of international jurisprudence on cross-border (or 'diagonal') human rights obligations, $i$. e., the possibility for human rights claims to be brought by individuals not under the territorial jurisdiction of the state whose international responsibility for environmental harm is invoked. So far the approach taken both by the Inter-American system and the European Court of Human Rights to extraterritorial obligations has been cautious. ${ }^{37}$ The Advisory Opinion makes clear that (i) in principle, crossborder human rights claims in respect of transboundary pollution and ecological damage are permissible under the American Convention, and (ii) such claims are not limited only to damages caused by a state's agents -rather, the IACtHR's jurisdiction would extend to activities over which a state exercises "effective control"-.${ }^{38}$

The Advisory Opinion emphasises that extraterritorial obligations are exceptional and should be restrictively construed. ${ }^{39}$ Even so, its principled and pragmatic handling of the concept of "effective control" is

\footnotetext{
10 rev.1, April 24, 1997, at para 190.

33 Advisory Opinion, $\$ 47$. (Our translation).

34 Advisory Opinion, $\$ 55$.

35 Convention for the Protection and Development of the Marine Environment of the Wider Caribbean Region, adopted Cartagena, Colombia, 24 March 1983, entered into force 11 October 1986.

36 Advisory Opinion, $\$ 126$.

37 For a detailed discussion on this aspect of the Advisory Opinion, see Feria-Tinta, M. \& Milnes, S. C., "The rise of environmental law in international dispute resolution: the InterAmerican Court of Human Rights issues a landmark advisory opinion on environment and human rights", Yearbook of International Environmental Law, 2018, 27 (forthcoming).

38 Id. See Advisory Opinion, at $\$ 104(\mathrm{~h})$.

39 Advisory Opinion, $\$ 81$ and $\$ 104(\mathrm{~d})$.
} 
an important development that should assist, in future, to avoid impunity for severe cross-border harms. With infrastructure megaprojects and other developments that have impacts on a similar scale, the magnitude of transboundary effects and their consequences challenge the traditional jurisdictional application of human rights treaties. In the context of transboundary harm, human rights recognised in UN and regional treaties would be de facto inoperable and meaningless unless the states that are the sources of these harms bear an international responsibility that is reasonably capable of being invoked under those treaties' accountability mechanisms, such as Article 63 of the American Convention. ${ }^{40}$

\section{(3) Due Diligence, the Duty to Prevent Transboundary Harm and Procedural Obligations}

In the IACtHR's analysis, the states' obligation to use due diligence is pivotal: the Court acknowledges that the majority of the environmental obligations rest on a duty of due diligence on the part of the state, ${ }^{41}$ understood as an obligation of conduct (i.e., focusing on what states do), and not as an obligation of result (focusing on whether states succeed in achieving a particular result or not). ${ }^{42}$

The Advisory Opinion draws heavily from the 1972 Stockholm Declaration ${ }^{43}$ and the 1992 Rio Declaration, ${ }^{44}$ treating the principles enunciated in those early non-binding legal instruments —including prevention of environmental harm, the precautionary principle, procedural safeguards, and the obligation of cooperation - as binding legal obligations under the American Convention. It also elaborates on the scope of a number of procedural rights such as access to information, public participation and access to justice.

\footnotetext{
40 Feria-Tinta, M. \& Milnes, S. C., "The rise of environmental law in international dispute resolution: the Inter-American Court of Human Rights issues a landmark advisory opinion on environment and human rights", Yearbook of International Environmental Law, 2018, 27 (forthcoming).

41 Advisory Opinion, at $\$ 124$.

42 Advisory Opinion, at $\$ 123$.

43 Declaration of the United Nations Conference on the Human Environment, Stockholm, June 5-16, 1972, un Doc. A/Conf.48/14/Rev. 1(1973); 11 ILM 1416 (1972).

44 Rio Declaration on Environment and Development, Rio de Janeiro, 13 June 1992. UN Doc. A/CONF.151/26 (vol. I); 31 ILM 874 (1992).
} 
The Court held in particular, that, in order to respect and guarantee rights to life and integrity, states are under a duty to:

i. Prevent significant environmental damage, both inside and outside their territory;

ii. Regulate, oversee and control the activities under their jurisdiction which may give rise to significant damage to the environment, carry out studies on environmental impact when there exists the risk of significant damage to the environment, draw up a contingency plan so as to have in place safety measures and procedures for minimising the possibility of major environmental accidents, and mitigating any significant environmental damage that would have ensued, even when this may have occurred in spite of preventive actions on the part of the state;

iii. Act in accordance with the precautionary principle, when faced with possible severe or irreversible damage to the environment, even in the absence of scientific certainty;

iv. Co-operate, in good faith, for the protection against damage to the environment;

v. Pursuant to that duty of co-operation, notify other states that may be potentially affected when they become aware that a planned activity under their jurisdiction could give rise to a risk of significant cross-border damage, and in cases of environmental emergencies, as well as consulting and negotiating, in good faith, with the states potentially affected by significant cross-border damage;

vi. Guarantee the right of access to information relating to possible negative impact upon the environment, enshrined in Article 13 of the American Convention;

vii. Guarantee the right to public participation of people under their jurisdiction, which is enshrined in Article 23(1) of the American Convention, in the making of decisions and policies that may affect the environment; and

viii. Guarantee access to justice, with regard to State obligations for the protection of the environment. ${ }^{45}$

45 Advisory Opinion, $\$ 242$. 


\section{(4) The Environment Itself as a Rights-Bearer}

Whilst the Stockholm and Rio Declarations postulate a human-centric approach, the Advisory Opinion pays attention to a recent phenomenon of granting legal protection to components of the environment, such as forests or rivers, as being in themselves the subjects of rights. Such an approach values not only the utility of nature for human beings but also its importance to the living organisms on the planet, having a claim in themselves to exist and flourish. ${ }^{46}$ The IACtHR noted that the Constitutions of some Latin American states, such as Bolivia and Ecuador, recognize inherent rights of nature. It also noted important judicial developments elsewhere that reflected the same approach: recent examples of the protection of nature in its own right by judicial means have arisen in Ecuador, ${ }^{47}$ Colombia, ${ }^{48}$ and India, ${ }^{49}$ where rivers have been granted legal personality. In Colombia, the Constitutional Court declared the Atrato river, whose delta is one of the "most biodiverse wildlife ecosystems in the world", 50 as a "subject of rights" entitled to "protection, conservation, maintenance and, in the concrete case, restoration", 51 and ordering the government to clean its waters that are contaminated with mercury. ${ }^{52}$ In New Zealand a similar protection has been conferred on the river Whanganui by law. ${ }^{53}$

The approach of recognizing the environment itself as a rightsbearer is proving effective in the struggles of indigenous communities across the American region to protect natural resources from extractive industries. First used to protect rivers, the device has also been applied

\footnotetext{
46 See, e.g., Advisory Opinion, $\$ 62$.

47 Constitutional Court of Ecuador, Judgment 218-15EP-CC, 9 July 2015.

48 Constitutional Court of Colombia, Judgment T-622-16, 10 November 2016.

49 Lalit Miglani v. State of Uttaarakhand and others, High Court of Uttarakhand at Naintal, India, Judgment of 30 March 2017.

50 Villa, Laura, "The importance of the Atrato river in Colombia", 17 May 2017, in https://www.earthlawcenter.org/blog-entries/2017/5/the-importance-of-the-atrato-riverin-colombia-gaining-legal-rights

51 "Corte asegura que el río Atrato tiene derechos y ordena recuperarlo", El Tiempo, 2 May 2017.

52 https://justiciaambientalcolombia.org/2017/05/07/sentencia-rio-atrato/, accessed on 27 April 2018.

53 https://www.parliament.nz/en/get-involved/features/innovative-bill-protects-whanganui-river-with-legal-personhood/, accessed on 28 April 2018.
} 
to forests. The most recent example is the Supreme Court of Colombia's granting of legal personality to the Colombian Amazon region, a rainforest which saw deforestation increase by $44 \%$ from 2015 to $2016 .{ }^{54}$ The Supreme Court ordered urgent measures to be taken by local government and central government to protect the Amazon from deforestation.

A similar subjectivity can be discerned in the bold move by Palau to create one of the world's largest ocean reserves. In Palau, traditional practices of environmental management known as bul combine intrinsic respect for nature with a functional means of keeping the society's development within what the ecosystem can support. ${ }^{55}$

These developments are examples of Judge Weeramantry's observation $^{56}$ that modern international law has much to learn from the ways in which ancient and traditional societies learned to co-exist with their environment, far more sustainably than the model currently being pursued by most countries.

54 Judgment STC4360-2018, 5 April 2018, in http://legal.legis.com.co/document?obra $=$ jurcol\&document=jurcol_c947ae53aeb447bd91e8e9a315311ac5, accessed on 25 April 2018.

55 See, e.g., Idechong, Noah, House of Delegates of Palau, submission to the United Nations on "Micronesian Sea Traditions - Palau's Marine Protected Areas", in http:/ / www. un.org/depts/los/consultative_process/documents/7abstract_idechong.pdf ("Surrounded by water, Palauans have developed a life which is inextricably linked with the oceans. We derive food, identity and traditions from our relationship with the ocean. The long standing success of this symbiotic relationship is based on responsibility that each Palauan is taught from childhood that they are caretakers of the sea [...] Palau's practical experience with the ecosystem approach extends back thousands of years. The traditional practice of bul is an important example. Bul involves the Council of Chiefs placing reef areas off limits to fishing during known fish spawning and feeding periods. This respects vulnerabilities in the ecosystem while ensuring that there will be robust fish to catch during other times of the year [...] Palau has banned all bottom trawling within its waters and by any Palauan or Palauan company anywhere in the world. Palauan law also obligates Palau to seek an interim prohibition on unregulated bottom trawling in international waters $[\ldots]$ In Palau it is more than just a saying, 'we do not inherit the earth from our parents, we borrow it from our children', it is a deeply held belief").

56 Gabč́kovo-Nagymoros Case, separate opinion of Justice Weeramantry, ICJ Reports, 1997, pp. 94-95. 


\section{Situating the Advisory Opinion in Context: A Time of Change and Reorientation in International Environmental Law}

We use the term 'international environmental law' to refer not to a defined body of law but more as a convenient shorthand for a collectivity - porous and ever-evolving - of international and transnational legal regimes that touch in some way on the environment, in all its aspects (human, natural, atmospheric, oceans, forests, rivers, groundwater, and so on). As such, it embraces not only those instruments which might first spring to mind, such as multilateral treaties on explicitly environmental subjects, but also instruments which regulate economic relationships such as trade, foreign investment and the activities of multilateral development banks, and global and regional human rights treaties which contain substantive and procedural norms that support protection of the environment and the rights and safety of its defenders. It also embraces relevant 'soft law' instruments adopted or endorsed by the international community, national regulations, and private sector and cross-sectoral initiatives that seek to govern transnational problems.

International environmental law is a young field: its emergence as a distinct body of law is usually dated to about $1972 .{ }^{57}$ It has evolved and expanded rapidly. ${ }^{58}$ As with the evolution of international law generally, international environmental law is the sum of the vectors acting upon it. It stands in a complex and ever-shifting relationship with other parts of international law, the international system itself, and pressures from states, ruling elites, business, civil society, and public opinion.

From this perspective, international environmental law stands today in a maelstrom of forces: a worsening danger of planetary collapse as fundamental ecological boundaries are crossed; ${ }^{59}$ turbocharged development, especially of infrastructure megaprojects and hydrocarbon extraction projects, many of doubtful utility; profound inequities in the distribution of the gains and harms from economic development and of the wastes

57 E. g., Fitzmaurice, M., Ong, D. M. \& Merkouris, P. (eds.), Research handbook on international environmental law, 2010, 15.

58 E. g., Brown Weiss, E., "The evolution of international environmental law", Japanese Y. B. Intl. L., 2011, 54, pp. 1-27.

59 See n. 3, supra. 
it generates; ongoing divisions between countries with different levels of wealth and capabilities; growing disorder in the international system; and growing doubts about the ability of international law to respond to these multiple threats in a divided world. Yet, despite the unpromising background, the Advisory Opinion, and indeed the Atrato and Amazon judgments, are not isolated developments but part of a discernible trend in contemporary international law. ${ }^{60}$ Moreover, much of the momentum behind this trend comes from countries in the global South, some of them places where environmental law scarcely existed only twenty years ago.

What explains this new dynamic? Myriad interrelated forces are at work. We identify four as especially significant. These are: (1) inescapable realities of planetary boundaries; (2) a turn to bottom-up approaches (given the failure of traditional top-down international governance approaches); (3) a shift in the long-problematic relationship between the global South and international environmental law; and (4) a new problem that international law itself - in its fragmented condition - can pose obstacles to the adoption of policies geared to the fulfilment of human rights and the protection of nature. We discuss these in more detail below.

These forces (among others) ${ }^{61}$ are, we contend, prompting a reorientation in international environmental law. If we are correct, the next phase will be characterized above all by (1) the increasing integration of international environmental law and human rights with other important bodies of international law, achieving the "defragmentation" of international law (properly conceived as a system) with both environmental and human rights concerns at its core; (2) more emphasis on the operationalization of existing (but so far inadequately implemented) norms and principles; and (3) a focus on remedies for environmental harms.

60 Feria-Tinta, M. \& Milnes, S. C., "The rise of environmental law in international dispute resolution: Inter-American Court of Human Rights issues landmark advisory opinion on environment and human rights", EJIL Talk!, Blog, 26 February 2018.

61 Clearly, no distillation of trends or schematization of causes such as those we put forward could hope to be an adequate account of the full complexity of developments occurring. Our argument below is offered as some bold, outline strokes (with all the invitation to debate which that implies). 


\section{A. The Vectors Acting on International Environmental Law}

We suggest that at the present conjuncture there are - among the innumerable forces at work - four key developments that are especially significant in pushing international environmental law into a particular new direction. We have encapsulated those four trends above, and here we seek to examine them in a little more detail. It is important to emphasize that these four trends are, in themselves, neither "harbingers of international happiness" ${ }^{\prime 2}$ nor "horsemen of the apocalypse". ${ }^{3}$ They are just processes - combinations of facts and of ideas which enjoy a certain currencyand they affect each other, ${ }^{64}$ even as they influence the overall direction of international environmental law.

\section{(1) Planetary Boundaries}

Things are bad. The present situation was well summarized by the Supreme Court of Colombia in the Amazon case:

Due to multiple simultaneous causes, derived, connected, or isolated, that negatively impact the ecosystem, environmental issues occupy a prominent place on the international agenda, not only of scientists and researchers, but also of politicians, the common people and, naturally, judges and lawyers. Day to day the news, articles and reports of different tiers presenting the gravity of the planetary conditions are abundant. There is a growing threat to the possibility of existence of human beings. ${ }^{65}$

62 To borrow the ironic phrase coined by Klabbers, Jan, "The life and times of the law of international organizations", Nordic J. Int'l L., 2001, 70, pp. 287, 288.

63 Greenwood, Christopher, "Is international law falling apart?", Public Lecture, Inner Temple, 15 March 2018.

64 For example, the first can fairly be regarded as a cause of the second and third. The fourth is partly responsible for the first, and might be a cause of the second (i. e., a reason why states look to extra-legal or non-legal policy initiatives instead of seeking to craft an improved multilateral framework).

65 Amazon case $\$ 4$. Unofficial translation by Dejusticia, in http://blogs2.law.columbia.edu/climate-change-litigation/wp-content/uploads/sites/16/non-us-case-documen ts/2018/20180405_11001-22-03-000-2018-00319-00_decision-1.pdf 
If we are to measure the success of international environmental law by its record in staving off a global environmental disaster, then it has been a great disappointment. Indeed, anyone who has read the preambles to the numerous multilateral environmental agreements concluded over the last three decades, and who also reads the news, cannot fail to experience a strange kind of cognitive dissonance. In the preambles, one reads that states have spotted some potential problems on the horizon and decided to take early, principled, equitable action to ensure that such unpleasant visions never come to pass. The international community speaks (with negotiated unanimity) of its own prudence, wisdom and stewardship, of balance, of sustainable development, of its willingness to moderate growth and consumption in the interests of environmental quality for this and future generations. Look anywhere else, though, and evidence for the existence of any such prudence, long-term thinking, stewardship, or inter-generational equity is vanishingly rare.

Just for instance, one may consider how the declared intentions of the three major multilateral legal instruments negotiated at the 1992 UN Conference on the Environment and Development at Rio de Janeiro stand up when measured against reality:

i. In the United Nations Framework Convention on Climate Change, ${ }^{66}$ enjoying near-universal participation, the international community pledges itself to the objective of "achiev[ing] [...] stabilization of greenhouse gas concentrations in the atmosphere at a level that would prevent dangerous anthropogenic interference with the climate system". ${ }^{67}$ How did we do? According to the 2014 synthesis report of the International Panel on Climate Change (an intergovernmental scientific organisation):

Throughout the $21^{\text {st }}$ century, climate change is expected to lead to increases in ill-health in many regions and especially in developing countries with low income, as compared to a baseline without climate change (bigh confidence). By $2100[\ldots]$ the combination of high temperature and humidity in some areas for parts of the year is expected to compromise common human activities,

${ }^{66}$ UN Treaty Series, vol. 1771 (p. 107), opened for signature at Rio de Janeiro, 4 June 1992, entered into force 21 March 1994.

67 Id. Article 2. 
including growing food and working outdoors (bigh confidence). In urban areas climate change is projected to increase risks for people, assets, economies and ecosystems, including risks from heat stress, storms and extreme precipitation, inland and coastal flooding, landslides, air pollution, drought, water scarcity, sea level rise and storm surges (very high confidence). These risks are amplified for those lacking essential infrastructure and services or living in exposed areas.

Rural areas are expected to experience major impacts on water availability and supply, food security, infrastructure and agricultural incomes, including shifts in the production areas of food and non-food crops around the world (bigh confidence). [...] From a poverty perspective, climate change impacts are projected to slow down economic growth, make poverty reduction more difficult, further erode food security and prolong existing and create new poverty traps, the latter particularly in urban areas and emerging hotspots of hunger (medium confidence) [...] Climate change is projected to increase displacement of people (medium evidence, high agreement). Populations that lack the resources for planned migration experience higher exposure to extreme weather events, particularly in developing countries with low income. Climate change can indirectly increase risks of violent conflicts by amplifying well-documented drivers of these conflicts such as poverty and economic shocks (medium confidence). ${ }^{68}$

Apart from that, it's all going pretty well.

That and the fact that ocean acidification caused by carbon dioxide being absorbed from the atmosphere by the seas appears set to wipe out the krill, the basis of many marine food chains. ${ }^{69}$

ii. In the United Nations Convention on Combating Desertification and Land Degradation, ${ }^{70}$ the Preamble acknowledges that "despite efforts

68 IPCC, “Climate Change 2014, synthesis report, summary for policymakers", in https:// www.ipcc.ch/pdf/assessment-report/ar5/syr/AR5_SYR_FINAL_SPM.pdf

69 E. g., Innis, M., "Warming oceans may threaten krill, a cornerstone of the Antarctic ecosystem”, New York Times, 19 October 2015.

70 UN Treaty Series, vol. 1954 (p. 3), adopted Paris, France, 14 October 1994, entered 
in the past, progress in combating desertification and mitigating the effects of drought has not met expectations and that a new and more effective approach is needed at all levels within the framework of sustainable development". After twenty-six years to find that "more effective approach", where are we? According to the Intergovernmental Science-Policy Platform on Biodiversity and Ecosystem Services (IPBES), $75 \%$ of the Earth's land area is degraded (on course to be $95 \%$ by 2050), ${ }^{71}$ undermining the wellbeing of two-fifths of humanity and with 24 billion tonnes of soil being lost every year. ${ }^{72} \mathrm{Oh}$, and "[b] y 2025, 1.8 billion people will experience absolute water scarcity, and $2 / 3$ of the world will be living under water-stressed conditions". ${ }^{73}$

iii. In the Preamble to the United Nations Convention on Biological Diversity, ${ }^{74}$ we meet an international community that is avowedly "[c]onscious of the intrinsic value of biological diversity" and "[d] etermined to conserve and sustainably use biological diversity for the benefit of present and future generations". Meanwhile, back in the real world, the sixth great extinction event in the history of the planet is getting underway. ${ }^{75}$ Whoops.

into force 26 December 1996.

71 Leahy, S., “75\% of Earth's land areas are degraded”, National Geographic, 26 March 2018, in https://news.nationalgeographic.com/2018/03/ipbes-land-degradation-environmentaldamage-report-spd/

72 Watts, J., "Land degradation threatens human wellbeing, major report warns", The Guardian, 26 March 2018, in https://www.theguardian.com/environment/2018/mar/26/ land-degradation-is-undermining-human-wellbeing-un-report-warns

73 This is the assessment of the UNCCD itself: see https://www.unccd.int/issues/landand-drought

74 UN Treaty Series, vol. 1760 (p. 79), adopted Rio de Janeiro, 5 June 1992, entered into force 29 December 1993.

75 Carrington, D., "Earth's sixth mass extinction event under way, scientists warn", The Guardian, 10 July 2017, in https://www.theguardian.com/environment/2017/jul/10/ earths-sixth-mass-extinction-event-already-underway-scientists-warn. See also Kolbert, Elizabeth, The sixth extinction: an unnatural history, 2014 (awarded the Pullitzer Prize); and Johnston, I., "Global mass extinction set to begin by 2100 , study finds", The Independent, 20 September 2017, in https://www.independent.co.uk/environment/mass-extinctionglobal-planet-start-year-2100-a7957886.html (reporting that "Earth appears to be on course for the start of a sixth mass extinction of life by about 2100 because of the amount of 
These were all binding treaties, not mere 'soft law'. Yet it would be hard to argue that the vast gulf between intention and actual performance results from any actual breach of obligations owed under any of these treaties by the states parties. The central problem is the absence - not the breach - of working-level norms capable of translating declarations of principle into effects which the atmosphere and biosphere can actually feel.

As the destruction continues, each successive global summit conference has had to acknowledge the international community's failure to implement the agenda from the previous one. At the Millennium Summit, the world's governments wagged their fingers in their own faces, intoning that, "[w]e must spare no effort to free all of humanity, and above all our children and grandchildren, from the threat of living on a planet irredeemably spoilt by human activities, and whose resources would no longer be sufficient for their needs". ${ }^{76}$ Two years later, the World Summit on Sustainable Development in Johannesburg mourned that: "[T] he global environment continues to suffer. Loss of biodiversity continues, fish stocks continue to be depleted, desertification claims more and more fertile land, the adverse effects of climate change are already evident, natural disasters are more frequent and more devastating, and developing countries more vulnerable, and air, water and marine pollution continue to rob millions of a decent life". ${ }^{77}$ As ever, the same intentions to improve environmental protection were announced; the predictable outcome was another decade spent busily sacrificing natural resources to short-term exploitation. Hence, ten years later, the Rio +20 Declaration had to admit (with diplomatic obliquity) that " [w] recognize that the 20 years since the United Nations Conference on Environment and Development in 1992 have seen uneven progress [...] We emphasize the need to make progress in implementing previous commitments. We also recognize the need to accelerate progress".

And so it goes on. A baby born during the 2002 Johannesburg summit is now a teenager nearing the end of high school: in her brief life so

carbon being pumped into the atmosphere, according to a mathematical study of the five previous events in the last 540 million years").

76 United Nations, Millennium Declaration, A/Res/55/2, para. 21, in https://www. un.org/millennium/declaration/ares552e.pdf

77 World Summit on Sustainable Development, Political Declaration, para. 13. 
far, she has lived through the burning of about $35 \%$ of the fossil fuels ever burned on earth. ${ }^{78}$ The situation is so baleful that some scholars have proposed that international law is by nature unfit for protecting global public goods and needs to be superseded by a less consensual system, a development which seems both unlikely and potentially dangerous. ${ }^{79}$

To be clear: by emphasizing the extent to which international lawmaking in the environmental field has failed to achieve its own stated objectives we are not intending to dismiss all international environmental law as useless. Far from it. Indeed, if the existing acquis of multilateral environmental agreements were done away with, this would likely cause a further massive deterioration in environmental quality, with the least developed countries and most vulnerable populations most severely affected because of the important role that multilateral funding plays in such matters as technology transfer, climate change adaptation, disaster risk management, and so on.

It is, however, vital to note that elaborating a coherent body of international legal principles, plus a large corpus of multilateral agreements on cooperation in environmental matters, has not so far been remotely sufficient to put the trajectory of real-world development onto a sustainable track. The principles elaborated in treaty preambles, in principlesetting articles (which in theory are binding as law but which contain no directly enforceable obligations), and indeed in pronouncements of the International Court of Justice, ${ }^{80}$ should be seen as only a beginning. The danger is that, instead, the preambles — and the principles they set outbecome a 'hall of mirrors' in which states and their representatives admire reflections, while outside the unremitting sacrifice of public goods for short-term private profit grinds ever on, pushing the planet further into

\footnotetext{
78 Any person can calculate the equivalent figure for themselves: see https://www. theguardian.com/environment/ng-interactive/2015/apr/10/how-much-fossil-fuel-arewe-using-right-now

79 Krisch, N. "The decay of consent: international law in an age of global public goods", Am. J. Int'l L., 2014, 108, pp. 1-40.

80 For example, the statement in the ICJ's Nuclear Weapons Advisory Opinion, para. 29, that " $[t]$ he existence of the general obligation of States to ensure that activities within their jurisdiction and control respect the environment of other States or of areas beyond national control is now part of the corpus of international law relating to the environment”. ICJ Reports, 1996, p. 242.
} 
unknown, unprecedented ecological conditions, ever more hostile to life generally and to ourselves.

In our assessment, the reality of looming planetary boundaries is slowly gaining recognition among judges (domestic and international), as well as other key stakeholders in the development of international environmental law, increasing their receptiveness to more innovative and radical measures.

\section{(2) The New World of Bottom-Up Initiatives}

Faced with the poor record of even negotiating multilateral top-down legal governance approaches, let alone implementing them in a manner that actually preserves some ecology, the international community has increasingly turned to bottom-up approaches. These stand in a different relationship to the system of international law from 'hard law' treaty obligations, but they nonetheless involve international law and exert an influence on its evolution.

Numerous examples could be given. At the international level, the 2009 Copenhagen Accord ${ }^{81}$ marked a historic shift away from the long and unsuccessful attempts at climate governance involving binding targets and timetables, to the "bottom-up" approach now enshrined in the 2015 Paris Agreement, ${ }^{82}$ under which States are to a great extent free to choose their own obligations (e.g., as regards the extent of greenhouse gas mitigation). At the same time, a "groundswell" of actions by subnational governments and the private sector, based on voluntary pledges and peer pressure, is helping both to achieve substantive reductions and encourage greater ambition on the part of national governments. ${ }^{83}$

\footnotetext{
81 “A legally non-binding political agreement", in https://unfccc.int/resource/docs/2009/ cop15/eng/107.pdf

82 Annexed to the UNFCCC, Decision adopting the Paris Agreement, FCCC/CP/2015/10/ Add.1, in https://unfccc.int/sites/default/files/resource/docs/2015/cop21/eng/10a01. pdf

83 See Chan, Sander, Falkner, Robert, Goldberg, Matthew \& Van Asselt, Harro, "Effective and geographically balanced? An output-based assessment of non-state climate actions", Climate Policy, 2016, 18, (1), pp. 24-35 (describing these developments as a "true groundswell" and providing an assessment of the geographical distribution of non-state and subnational initiatives). Detail on pledges by subnational regions, cities and corporations can be found in the Non-state Actor Zone for Climate Action (NAZCA) portal of the
} 
It is a model which has been imitated outside the climate regime: numerous countries have made bottom-up pledges to restore degraded lands under the Bonn Challenge, ${ }^{84}$ and the UNCCD has adopted a bottom-up target-based approach in aiming to achieve net land degradation neutrality by $2030 .{ }^{85}$ National governments are increasingly taking unilateral steps to discourage unsustainable practices, such as banning single use plastics. ${ }^{86}$

Although this might initially appear paradoxical, the trend towards bottom-up initiatives is in fact leading to more stringent and enforceable legal norms being introduced, the aforementioned plastic bans being a good example.

\section{(3) The Changing View from the Global South}

The predicaments facing Southern countries are complex and differentiated. They do not lend themselves to generalizations. To colleagues working in developing countries who consider that in the below we omit something important about their (or any) countries' situations: we are sure that you are right. Nor is this the place to analyse the important debates over the concept of "differentiation" in rights and obligations, both between developed and developing countries and between different groups of developing countries, such as the special position of least developed countries and small island developing states. ${ }^{87}$ What we offer here is only a first approximation; nonetheless, our assessment is that an important change is afoot which merits attention of scholars and policymakers alike.

UNFCCC's website, established as part of the 2014 Lima-Paris Action Agenda which helped to build momentum towards the Paris Agreement: see http://climateaction.unfccc.int/

84 See http://www.bonnchallenge.org/content/challenge

85 See https://www.unccd.int/actions/ldn-target-setting-programme

86 At the time of writing, three African countries (Rwanda, Kenya and Uganda) have banned the manufacture of plastic bags: "Museveni bans plastic bags in Uganda", The Star (Kenya), 6 June 2018, in https:/ / www.the-star.co.ke/news/2018/06/06/museveni-bansplastic-bags-in-uganda_c1768869. Taiwan has announced a phased ban on all single use plastic: "Taiwan announces ban on all plastic bags, straws, and utensils", Global Citizen, 22 February 2018 (reporting phased restrictions leading to total ban on single use plastic by 2030), in https://www.globalcitizen.org/en/content/taiwan-ban-on-plastic-bags-strawsutensils-contain/

87 See, e. g., Different perspectives on differentiated responsibilities, Deutsches Institut für Entwicklungspolitik research paper, 2014. 
The relationship between developing countries and the evolution of international environmental law has never been straightforward. ${ }^{88}$ International environmental law emerged at the very point when developing countries were engaged in a struggle to alter the international system to promote their faster economic development and establish a "New International Economic Order". Those struggles left a profound mark on the Stockholm and Rio Declarations. ${ }^{89}$ Many developing country governments felt that the Stockholm conference was an attempt to impose the North's concerns over the consequences of the North's development on them, and risked impeding their economic development in the name of protecting values (wildlife, the atmosphere) which the North had the luxury of being concerned about since it did not have to face immediate daily problems of starvation, disease and squalor besetting poor countries. ${ }^{90}$ The very history of the international environmental law itself can be seen as the story of how blocs of countries at different stages of development have battled over the principles of differentiation and financial aid, of how much effort at contributing to tackling global problems can be expected from the poorest, and in return for what degree of assistance from wealthier nations.

Today, international environmental law has certainly not escaped this dynamic. But other dynamics have also entered the equation. Overall, the global South is today far from sceptical about the need for international environmental law. At government level, developing countries have played a key role in pressing for more effective legal regimes: examples include the

88 For an excellent examination of this multifaceted topic, see Alam, Shawkat, Atapattu, Sumudu, Gonzalez, Carmen G. \& Razzaque, Jona (eds.), International environmental law and the Global South, Cambridge, 2015.

89 See, for example, Stockholm Declaration, Principle 1 ("Policies promoting or perpetuating apartheid, racial segregation, discrimination, colonial and other forms of oppression and foreign domination stand condemned and must be eliminated"), Principle 9 ("Environmental deficiencies generated by the conditions of under-development and natural disasters pose grave problems and can best be remedied by accelerated development through the transfer of substantial quantities of financial and technological assistance as a supplement to the domestic effort of the developing countries and such timely assistance as may be required") and Principle 21 ("States have, in accordance with the Charter of the United Nations and the principles of international law, the sovereign right to exploit their own resources").

90 Kotzé, Louis, "Human rights, the environment and the Global South", in Alam, S. et al. (eds.), n. 89 above, 172. 
trade in toxic chemicals, ${ }^{91}$ and moves towards regulating the human rights impact of business. ${ }^{92}$ Concern at the level of civil society is even greater.

This shift is both real and rational. The Stockholm Declaration was accurate, in 1972, when it said that most of the environmental problems then facing poorer countries were caused by under-development and could be solved by increased wealth. ${ }^{93}$ A half-century on, much development has occurred. Southern countries now experience environmental problems that are side effects of development, not only effects of under-development. There are question-marks over how viable or beneficial some of the development has been. Much development in the global South has taken the form of cash crop agribusiness and mining, as opposed to manufacturing and services. Agricultural products and extracted raw materials (coal, crude oil, metal ores, etc.) are today produced and exported on a scale vastly exceeding the South's economy in 1972. This has resulted in both high GDP figures and a raft of new problems, from contamination of the land, deforestation, land degradation and desertification, loss of biodiversity, water shortages, and, of course, climate change. Attitudes in the South towards global environmental problems have changed as Southern countries began to feel the local impacts of global problems. ${ }^{94}$

91 Some seventeen African countries are parties to the Bamako Convention on the Ban of the Import into Africa and the Control of Transboundary Movement and Management of Hazardous Wastes within Africa, UNTS, 2102, p. 177, adopted Bamako, Mali, 31 January 1991, entered into force 22 April 1998.

92 Developing country members of the UN Human Rights Council overwhelmingly supported (whereas developed country members generally opposed) HRC Resolution 26/9 (A/ HRC/RES/26/9) which decided "to establish an open-ended intergovernmental working group on transnational corporations and other business enterprises with respect to human rights; whose mandate shall be to elaborate an international legally binding instrument to regulate, in international human rights law, the activities of transnational corporations and other business enterprises".

93 "Environmental deficiencies generated by the conditions of under-development and natural disasters pose grave problems and can best be remedied by accelerated development through the transfer of substantial quantities of financial and technological assistance as a supplement to the domestic effort of the developing countries and such timely assistance as may be required". Stockholm Declaration, Principle 9.

94 Atapattu, Sumudu, "The significance of international environmental law principles in reinforcing or dismantling the North-South Divide", in Alam, S. et al. (eds.), n. 89, supra, 78 (footnote 29). 
In the 1970s and 1980s, in the immediate aftermath of the struggle to establish the principle of Permanent Sovereignty over Natural Resources, most of the resources at issue lay still undisturbed beneath the rainforests and grasslands of the developing world. Postcolonial states experimenting with socialism, and various forms of corporatism, often lacked the resources to extract and monetize those resources at any great speed. Neoliberal fiscal and economic policies from 1989 onwards changed this picture. Quite suddenly, local communities and indigenous peoples across the developing world found themselves on the frontline of a resource extraction boom. Enforcement of environmental law could mean the difference between life and death.

In this context, the pressure for more effective environmental law and accountability for transnational corporations is only to be expected. Some of the most paradigmatic environmental disasters of our time have occurred as a consequence of the non-observance of basic due diligence standards. The environmental crisis caused by a devastating mercury spill in a peasant village in Peru's Andean mountains, by the world's richest gold mining corporation, chronicled in the award-winning documentary Choropampa: The Price of Gold, illustrates this, as does some pioneering case law in the Inter-American and African systems, such as Community of San Mateo Huanchor ${ }^{95}$ (a case concerning severe environmental pollution caused by toxic mining waste) and Mapuche Paynemil and Kaxipayiñ Communities v. Argentina $^{96}$ (a Mapuche community exposed to consumption of water contaminated with lead and mercury) and Social and Economic Rights Action Centre and the Center for Economic and Social Rights v. Nigeria ${ }^{97}$ (concerning failure of Nigeria to prevent pollution and ecological degradation to the detriment of the Ogoni people).

Indeed, the situation of indigenous peoples threatened by the proposed canal in Nicaragua is a classic example: the communities seeking to

\footnotetext{
95 Inter-American Commission on Human Rights, Report 69/04, Petition 504/03, Admissibility, 15 October 2004.

96 Inter-American Commission on Human Rights, Case 12010. Pending before the Inter-American Commission, in https://www.escr-net.org/es/caselaw/2006/comunidadesmapuche-paynemil-y-kaxipayin-caso-no-12010

97 African Commission on Human and People's Rights, Communication 155/96. For a full review of this case see Feria-Tinta, M., "Litigation in regional human rights systems on economic, social and cultural rights against poverty", in Van Bueren, G. (ed.), Freedom from poverty as a buman right, UNESCO Publishing, 2009.
} 
bring contentious proceedings before the Inter-American Commission on Human Rights have claimed that:

The proposed route of the canal will directly affect protected areas and it would mean the destruction of 193 thousand hectares of diverse woodland, an irreparable loss of natural assets that provide incalculable services to the eco-system, which guarantee the water sustainability of the country and are home to our biological wealth [...] But the greatest and most dangerous threat of all is the one that hangs over our Great Lake Cocibolca (Lake Nicaragua), which is established as the most important fresh water reservoir of Central America, and the richest lake in the Americas for its ecological, environmental and economic value. The scientific community has already warned that the canal project is subjecting it to severe threats of contamination by hydrocarbons, risks of salinization, sedimentation, water turbidity and invasion from alien species, the outcomes of which would be truly catastrophic. ${ }^{98}$

In all, the North-South dynamic has changed noticeably. Much of the South now finds itself in a state of turbocharged development, but one where most of the economic value generated accrues to the highvalue-adding economies of the North — in effect, to the West and to industrialized Northeast Asia (China, Japan, South Korea and Asia's offshore financial hubs) — while the externalities of such growth, in the form of wastes, contamination, land degradation, water shortages and biodiversity loss, are felt in the places where the raw materials are extracted and produced, that is, primarily in the Global South.

In this disquieting scenario, it is therefore perhaps of little wonder that some of the most sophisticated and innovative thinking on international environmental law is today emanating from the South.

\section{(4) International Law -in Its Fragmented Condition- Can Even Be a Threat to Human Rights and the Environment}

Another development which is serving as a powerful impetus to rethink the role of international environmental law is the growth of fragmented

98 See "Concesión del canal interoceánico en Nicaragua: grave impacto en los derechos humanos - Comunidades campesinas movilizadas resisten”, supra n. 17 at p. 5. (M. FeriaTinta's translation). 
(arguably even de facto "self-contained") regimes in international law which have — whatever their original intentions - proved to be obstacles to the adoption of sound environmental policies.

We do not wish to exaggerate this phenomenon, and certainly we do not suggest it is a necessary or permanent feature of international law. As set out below, our view is that international law is a system. There is ample room in it to allow for the operationalizing of international environmental law principles, especially when its fabric is properly defragmented. ${ }^{99}$

Nonetheless, today's world clearly differs from 1972 in this respect: in 1972, a developing country that chose to adopt strong measures of environmental protection, restricting harmful activities and imposing tax disincentives on unsustainably produced goods would have faced few obstacles arising from international law to its "people and planet" policies. Today, most developing countries are members of the WTO and many are party to numerous bilateral (and in some cases multilateral) investment treaties, whose obligations have proven something of a straitjacket against environmental measures. Recent examples of such tension between environmental law and investment law in investment arbitration cases include Minera Aratari v. Uruguay, ${ }^{100}$ and Eco Oro Mining v. Colombia. ${ }^{101}$ International law itself, in its fragmented condition, has come to be an ambiguous player in the sustainable development game —at one level, upholding principles whereby states should pursue environmental protection, and yet at the same time furnishing economic actors disadvantaged by environmentally protective measures with powerful weapons to pressure states for their reversal - This phenomenon creates an impetus to reorient international law so as to reduce conflicts of norms.

99 Schill, Stephan W., Tams, Christian J. \& Hoffman, Rainier (eds.), International investment law and development: bridging the gap, 2015.

100 A US $\$ 3.5$ billion investment treaty claim under UNCITRAL rules, against Uruguay, over a concession to mine for iron ore. The claim revolves around "right to regulate" issues: Uruguay's passing of greater environmental and financial regulations on large-scale mining projects. Jones, Tom, "Uruguay will face multibillion-dollar claim”, GAR, 8 August 2018. 101 Eco Oro Minerals Corp. v. Republic of Colombia, ICSID Case ARB/16/41. For a discussion of the environmental issues concerning the Colombian Paramo and its protection see CIEL, "Protecting the Colombian paramo from eco oro mining", in https://www.ciel. org/project-update/eco-oro/ 


\section{B. A Period of Change and Reorientation in International Environmental Law}

The abovementioned forces do not preordain any particular outcome, but in our view (a) these trends are conducive to reorienting international environmental law in the directions outlined below, and $(b)$ this would be a positive development. The present conjuncture calls for difficult and specialist work in taking advantage of these forces in order to make international environmental law more effective in achieving the objectives which states have repeatedly pledged to achieve. The urgently needed rebalancing of international environmental law will involve

(1) Integration of international environmental law and human rights with other fields of international law;

(2) Operationalization of principles through working-level binding norms; and

(3) The fashioning of practical remedies to give force to legal norms.

On each of those aspects, the Advisory Opinion on Environment and Human Rights has made a meaningful contribution.

\section{(1) Integration and De-Fragmentation}

An aspect of international law's rapid development in response to the increasing complexity of modern economic and social life is the emergence of new and distinct fields, in which international legal norms have evolved in relative isolation from others. This "fragmentation" of international law has generated widespread concern. In some cases, it has even been proposed that some areas constitute "self-contained regimes" to which general principles of pubic international law do not apply or which need not be harmonised with other fields of international law. Even where there was in theory no suggestion of a "self-contained regime", in practice the reality often came to resemble just that. The consequence of fragmentation was that certain areas of law —usually those with the most puissant dispute resolution provisions - came to exercise a disproportionate sway over the states' ability to regulate, and thus over the trajectory of the countries' development, while the norms from other fields of international law fell de facto into desuetude. 
International investment law is a conspicuous example of a field ${ }^{102}$ that has developed with insufficient connection to the rest of public international law (not least environmental law and human rights law). To some, the system appears intrinsically unbalanced and unfavourable to developing countries, despite valid and understandable motives for concluding BITs. ${ }^{103}$ One detailed study of investor-state awards found evidence of widespread failure to apply international law's rules of treaty interpretation reflected in the Vienna Convention on the Law of Treaties when interpreting BITs. ${ }^{104}$ Yet investment arbitration is not escaping the impact of the growing importance of environmental and human rights rules. ${ }^{105}$ An example of a case in which a state successfully defended an investor-state arbitration on environmental law grounds is Oceana Gold v. El Salvador. ${ }^{106}$

Overall, the current trend is very much against endorsing any proliferation of self-contained regimes. As the International Law Commission held in its authoritative study on "Fragmentation of International Law", "[i]n International Law, there is a strong presumption against normative conflict". ${ }^{107}$ There is only one international community, and its members — primarily the States — need to know what their obligations are in or-

102 We use this term because international investment law is perhaps too decentralized and bilateral to be described as a 'regime'.

103 E. g., Guzman, Andrew T., "Why LDCs sign treaties that hurt them: explaining the popularity of bilateral investment treaties", Va. J. Int'l L., 1997, 38, p. 639; Van Harten, Gus, Investment treaty arbitration and public law, OUP, 2007.

104 Hai Yen, Trinh, The interpretation of investment treaties, Brill, 2014, passim.

105 See for example, Feria-Tinta, M., "Like oil and water? Human rights in investment arbitration in the wake of Philip Morris v. Uruguay", The Journal of International Arbitration, 34, (4), pp. 601-630.

106 Oceana Gold v. El Salvador (Pac Rim Cayman LLC v. Republic of El Salvador), ICSID Case $\mathrm{ARB} / 09 / 12$. The investor sought a green light for its "El Dorado" mine, or approximately US $\$ 300$ million in compensation. El Salvador prevailed, showing that the investor had failed to meet key regulatory requirements such as (i) environmental impact study, (ii) feasibility study, and (iii) land title and mining permit.

107 ILC, "Fragmentation of international law: difficulties arising from the diversification expansion of international law", report on the Study Group of the International Law Commission (prepared by Martti Koskenniemi) UN doc A/CN.4/L.682 (13 Apr. 2006) at para. 37. For an in-depth analysis of the key issues concerning a non-fragmented vision of international law see Feria-Tinta, M., "Like oil and water? Human rights in investment arbitration”, n. 106, supra, in particular pp. 606-609. 
der for anything resembling a stable, peaceful order to exist. Purposeful integration is the route to achieving this. ${ }^{108}$

\section{(2) Operationalization of Principles through Working- Level Norms}

The work of elaborating principles is done. Whilst (as noted above) the achievements of international environmental law's first four decades are painfully inadequate in terms of impact, the years between Stockholm and Rio +20 have at least produced a body of serviceable principles backed by solid opinio juris. The task ahead is to mediate between the Heaviside Layer of multilaterally agreed principles and the branches of law that actually exert a direct influence over human activities. This means ensuring that working-level norms reflect and serve those principles. In our view, regional human rights treaties such as the American Convention will prove an essential roadmap in guiding this process. Human rights law has grown, slowly but steadily, into a significant source of legal obligations on states. As the Advisory Opinion makes clear, the environment and human rights are indivisibly interrelated.

Moreover, the Advisory Opinion shows how existing norms can be made more effective by proper judicial explication. Difficult as it may be for the international community to negotiate new multilateral rules to avert environmental harms, the rights and obligations that exist already cannot simply be ignored. An understanding of the ways in which environmental harm can violate existing rights (such as the rights to life and personal integrity in articles 4 and 5 of the American Convention) means that certain conduct by states causing environmental destruction is already illegal and triggers State responsibility, even without any further law-making at the international level. ${ }^{109}$ The Inter-American Court's Advisory Opinion has achieved something remarkable in that sense. It has constitutionalized the right to a healthy environment as a basic right, and has given it teeth throughout the "Convention space" which the Pact of San José creates.

\footnotetext{
108 E. g., M. Feria-Tinta, n. 106, supra.

109 Bodansky, D., Brunnée, J. \& Rajamani, L., International climate change law, Oxford, 2017, p. 299.
} 


\section{(3) A Focus on Practical Remedies}

The third necessary feature of a reinvigorated international environmental law must be a focus on practical remedies for victims of environmental harms. The first and second features are necessary supports to this effort: effective remedies can hardly exist without integration and operationalization of working-level legal norms. By the same token, fashioning principles into working-level law means fashioning remedies. The Advisory Opinion is a step forward in that direction, particularly in confirming that crossborder jurisdiction may exist for serious transboundary harms originating under the "effective control" of a state that fails to comply with the existing norms of international environmental law, including environmental impact assessment and good faith consultation with other affected states.

These three characteristics of the emerging phase which we identify are closely interrelated: defragmentation will permit and promote the operationalization of environmental norms in other, previously more separate, fields of legal regulation, such as the law governing treatment of foreign investment. Both defragmentation and operationalization will be necessary to implement meaningful remedies that redress harm in specific cases and encourage states and other actors to respect human rights and environmental norms in the wider interest. In a sense, all three could be seen as aspects of one single objective, the rebalancing of international law - away from trends which have anomalously privileged a select few types of economic interests and towards a more holistic approach to sustainable human development-.

\section{Conclusion}

It was a quirk of history that human rights and international environmental law were born at different times. The main universal human rights instruments (the Universal Declaration of Human Rights — UDHR - of 1948, the ICCPR and ICESCR of 1966) were drawn up before environmental issues featured on the international agenda in any significant way. The same can be said of some of the leading regional instruments such as the American Declaration (1948 — preceding even the UDHR-), the American Convention on Human Rights (1969) and the European Convention on Human Rights (1950). Had human rights been "discovered" a generation later, their founding texts would have been informed by the diverse environmental concerns that both Northern and Southern countries respectively aired 
at Stockholm in 1972 and which are reflected in the Rio Declaration. Instead, their separation at birth (so to speak) has posed serious challenges for both human rights law and international environmental law, which are still in the process of being overcome.

There remain real doubts about the ability of international law itself, a system based essentially on the consent of nearly two hundred sovereign states, to adopt measures sufficiently strong and coherent to be capable of protecting the Earth's highly (if fleetingly) monetizable resources from the grasp of their own most powerful citizens, for the benefit of unborn generations and the weak. But international law is, in reality, not the work of a single creator. Tensions abound. The enduring strength of public international law has proved to be its indivisibility, its openness to integration. Many predictions of the emergence of self-contained regimes here or there (e.g., the WTO) have disintegrated upon colliding with the surprisingly heavy submerged object — the pull towards the highest animating values behind international law-. In the present conjuncture, survival —of modern civilisation, our species, and even Earth's multifarious but fragile living systems - is the most urgent of these values, truly a "universal interest, which is owed both to present and future generations" and "a fundamental right for the existence of humanity". ${ }^{110}$

\section{References}

\section{Books and Articles}

"Corte asegura que el río Atrato tiene derechos y ordena recuperarlo", El Tiempo, 2 May 2017.

"How much fossil fuel has been used in your lifetime", The Guardian, in https://www.theguardian.com/environment/ng-interactive/2015/ apr/10/how-much-fossil-fuel-are-we-using-right-now

"Museveni bans plastic bags in Uganda", The Star, 6 June 2018, in https:// www.the-star.co.ke/news/2018/06/06/museveni-bans-plastic-bagsin-uganda_c1768869

"Taiwan announces ban on all plastic bags, straws, and utensils", Global Citizen, 22 February 2018, in https://www.globalcitizen.org/en/ content/taiwan-ban-on-plastic-bags-straws-utensils-contain/

110 Advisory Opinion, $₫ 59$. 
Ahmed, N., "Nasa-funded study: industrial civilisation headed for 'irreversible collapse'?", The Guardian, 14 March 2014.

Alam, S., Atapattu, S., Gonzalez, C. G. \& Razzaque, J. (eds.), International environmental law and the Global South, Cambridge University Press, Cambridge, 2015.

Atapattu, S., "The significance of international environmental law principles in reinforcing or dismantling the North-South Divide", in Alam, S. et al., International environmental law and the Global South, Cambridge University Press, Cambridge, 2015.

Barnosky, A. D. et al., "Approaching a State shift in Earth's biosphere", Nature, January 2012.

Bodansky, D., Brunnée, J. \& Rajamani, L., International climate change law, OUP, Oxford, 2017.

Brown Weiss, E., "The evolution of international environmental law", Japanese Y. B. Intl. L., 2011, 54, pp. 1-27.

Carrington, D., "Earth's sixth mass extinction event under way, scientists warn", The Guardian, 10 July 2017, in https://www.theguardian. com/environment/2017/jul/10/earths-sixth-mass-extinction-eventalready-underway-scientists-warn

Centre for International Environmental Law, "Protecting the Colombian paramo from eco oro mining", in https://www.ciel.org/projectupdate/eco-oro/

Chan, S., Falkner, R., Goldberg, M. \& Van Asselt, H., "Effective and geographically balanced? An output-based assessment of non-state climate actions", Climate Policy, 2016, 18, (1), pp. 24-35.

Dejusticia, "Sentencia T-622 de 2016 que reconoce al río Atrato como sujeto de derechos", in https://justiciaambientalcolombia. org/2017/05/07/sentencia-rio-atrato/

Deutsches Institut für Entwicklungspolitik, Different perspectives on differentiated responsibilities, research paper, 2014.

Feria-Tinta, M. \& Milnes, S. C., "How international law could help victims of environmental degradation”, The Guardian, 21 February 2018.

Feria-Tinta, M. \& Milnes, S. C., "The rise of environmental law in international dispute resolution: the Inter-American Court of Human Rights issues a landmark advisory opinion on environment and human rights", Yearbook of International Environmental Law, 27, pp. 1-18 (forthcoming).

Feria-Tinta, M. \& Milnes, S. C., "The rise of environmental law in international dispute resolution: Inter-American Court of Human Rights 
issues a landmark advisory opinion on environment and human rights", EJIL Talk!!, Blog, 26 February 2018.

Feria-Tinta, M., "Like oil and water? Human rights in investment arbitration in the wake of Philip Morris v. Uruguay", The Journal of International Arbitration, 34, (4), pp. 601-630.

Feria-Tinta, M., "Litigation in regional human rights systems on economic, social and cultural rights against poverty", in Van Bueren, G. (ed.), Freedom from poverty as a buman rights, UNESCO Publishing, 2009.

FIDH, "Concesión del canal interoceánico en Nicaragua: grave impacto en los derechos humanos - Comunidades campesinas movilizadas resisten", September 2016 No 680, in https:/ /www.fidh.org/IMG/ pdf/nicaragua680esp2016web-1gg.pdf

Fitzmaurice, M., Ong, D. M. \& Merkouris, P. (eds.), Research handbook on international environmental law, Edward Elgar Publishing Ltd, Cheltenham, 2010.

Gibbs, S. \& Elliott, L., "China puts Nicaraguan canal plan on hold", The Times, 19 June 2017.

Greenwood, C., "Is international law falling apart?", Public Lecture, Inner Temple, 15 March 2018.

Guzman, A. T., "Why LDCs sign treaties that hurt them: explaining the popularity of bilateral investment treaties", Va. J. Int'l L., 1997, 38, p. 639.

Hai Yen, Trinh, The interpretation of investment treaties, Brill-Nijhoff, Leiden, 2014.

Idechong, N., House of Delegates of Palau, Submission to the United Nations on "Micronesian Sea Traditions - Palau's Marine Protected Areas", in http://www.un.org/depts/los/consultative_process/ documents/7abstract_idechong.pdf

Innis, M., "Warming oceans may threaten krill, a cornerstone of the Antarctic ecosystem", New York. Times, 19 October 2015.

Johnston, I., "Global mass extinction set to begin by 2100 , study finds", The Independent, 20 September 2017, in https://www.independent. co.uk/environment/mass-extinction-global-planet-start-year2100-a 7957886.html

Jones, T., "Uruguay will face multibillion-dollar claim", Global Arbitration Review, 8 August 2018.

Klabbers, J., "The life and times of the law of international organizations", Nordic J. Int'l L., 2001, 70, pp. 287, 288. 
Kolbert, E., The sixth extinction: an unnatural history, Bloomsbury, London, 2014.

Kotzé, L. "Human rights, the environment and the Global South", in Alam, S. et al., International environmental law and the Global South, Cambridge University Press, Cambridge, 2015.

Krisch, N., "The decay of consent: international law in an age of global public goods", Am. J. Int'l L., 2014, 108, pp. 1-40.

Leahy, S., "75\% of Earth's land areas are degraded", National Geographic, 26 March 2018, in https:/ / news.nationalgeographic.com/2018/03/ ipbes-land-degradation-environmental-damage-report-spd/

Schill, S. W., Tams, C. J. \& Hoffman, R. (eds.), International investment law and development: bridging the gap, Edward Elgar Publishing Ltd, Cheltenham, 2015.

Van Harten, G., Investment treaty arbitration and public law, OUP, Oxford, 2007. Villa, L., "The importance of the Atrato river in Colombia", 17 May 2017, in https://www.earthlawcenter.org/blog-entries/2017/5/ the-importance-of-the-atrato-river-in-colombia-gaining-legal-rights

Watts, J., "Land degradation threatens human wellbeing, major report warns", The Guardian, 26 March 2018, in https:/ /www.theguardian. com/environment/2018/mar/26/land-degradation-is-undermininghuman-wellbeing-un-report-warns

\section{Official documents}

Additional Protocol to the American Convention on Human Rights in the Area of Economic, Social and Cultural Rights El Salvador, San Salvador, November 17, 1988. OAS Treaty Series, No 69.

African Commission on Human and People's Rights, Social and economic rights action centre and the Center for Economic and Social Rights v. Nigeria, Communication 155/96.

American Convention on Human Rights (Pact of San José), San José, Costa Rica, 1969, OAS Treaty Series, No 36.

Bamako Convention on the Ban of the Import into Africa and the Control of Transboundary Movement and Management of Hazardous Wastes within Africa, UNTS Vol. 2102.

Bonn Challenge, website, in http://www.bonnchallenge.org/content/ challenge

Convention for the Protection and Development of the Marine Environment of the Wider Caribbean Region, Cartagena, Colombia, 1986. 
Copenhagen Accord, in https://unfccc.int/resource/docs/2009/cop15/ eng/107.pdf

Declaration of the United Nations Conference on the Human Environment, Stockholm, June 5-16, 1972, un Doc. A/Conf.48/14/Rev. 1(1973); 11 ILM 1416 (1972).

Inter-American Commission on Human Rights, Community of San Mateo Huanchor, Report 69/04, Petition 504/03, Admissibility, 15 October 2004.

Inter-American Commission on Human Rights, "Indigenous and tribal people's rights over their ancestral lands and natural resources, norms and jurisprudence of the Inter-American Human Rights System", 30 December 2009. OEA/Ser.I/L/V/II. Doc. 56/09.

Inter-American Commission on Human Rights, Report on the situation of buman rights in Ecuador. Doc OE/Ser.L/V/II.96, Doc. 10 rev.1, April 24, 1997.

Intergovernmental Panel on Climate Change, "Climate Change 2014, synthesis report, summary for policymakers", in https:/ / www.ipcc.ch/ pdf/assessment-report/ar5/syr/AR5_sYR_FINAL_SPM.pdf

International Law Commission, "Fragmentation of international law: difficulties arising from the diversification expansion of international law: report on the study Group of the International Law Commission" (prepared by Martti Koskenniemi), un Doc A/CN.4/L.682 (13 Apr. 2006).

New Zealand Parliament, "Innovative bill protects Whanganui river with legal personhood", in https://www.parliament.nz/en/getinvolved/features/innovative-bill-protects-whanganui-river-withlegal-personhood/

Paris Agreement on Climate Change, FCCC/CP/2015/10/Add.1, in https://unfccc.int/sites/default/files/resource/docs/2015/cop21/ eng/10a01.pdf

Rio Declaration on Environment and Development, Rio de Janeiro, 13 June 1992, un Doc. A/CONF.151/26 (vol. I); 31 ILM 874 (1992).

UNCCD, "Land and drought", in https://www.unccd.int/issues/land-anddrought

UNCCD, "Land degradation neutrality targets", in https://www.unccd.int/ actions/ldn-target-setting-programme

UNFCCC \& NAZCA, "Non-state and subnational climate actions", in http:/ / climateaction.unfccc.int/ 
United Nations Convention on Biological Diversity, UN Treaty Series, Vol. 1760 (p. 79), adopted Rio de Janeiro, 5 June 1992.

United Nations Convention on Combating Desertification and Land Degradation, UN Treaty Series, Vol. 1954 (p. 3).

United Nations Framework Convention on Climate Change, 1992, UN Treaty Series, Vol. 1771 (p. 107).

United Nations Human Rights Council Resolution 26/9, UN Doc. A/ $\mathrm{HRC} / \mathrm{RES} / 26 / 9$.

United Nations Human Rights Council, Preliminary report of the independent expert on the issue of human rights obligations relating to the enjoyment of a safe, clean, bealthy and sustainable environment, John H. Knox, 24 December 2012, un Doc. A/HRC/22/43.

United Nations, Millennium Declaration, A/Res/55/2.

World Summit on Sustainable Development, Political Declaration.

\section{Court Judgements, Laws}

Colombian Supreme Court Judgment STC4360-2018, 5 April 2018, in http:/ / legal.legis.com.co/document?obra $=$ jurcol\&document $=$ jur col_c947ae53aeb447bd91e8e9a315311ac5 (Unofficial translation by Dejusticia, in http://blogs2.law.columbia.edu/climate-changelitigation/wp-content/uploads/sites/16/non-us-case-documen ts/2018/20180405_11001-22-03-000-2018-00319-00_decision-1. pdf)

Constitutional Court of Colombia, Judgment T-622-16,10 November 2016.

Constitutional Court of Ecuador, Judgment 218-15EP-CC, 9 July 2015.

High Court of Uttarakhand at Naintal, India, Lalit Miglani v. State of Uttaarakhand and others, Judgment of 30 March 2017.

Inter-American Commission on Human Rights, Mapuche Paynemil and Kaxipayiñ Communities v. Argentina, Case 12.010.

Inter-American Court of Human Rights, The environment and buman rights - State obligations in relation to the environment in the context of the protection and guarantee of the rights to life and to personal integrity - Interpretation and scope of articles 4(1) and 5(1) of the American Convention on Human Rights—, Advisory Opinion OC-23/18, (ser. A), No 23, 15 November 2017.

International Centre for the Settlement of Investment Disputes, Eco Oro Minerals Corp. v. Republic of Colombia, ICSID Case ARB/16/41. 
International Centre for the Settlement of Investment Disputes, Oceana Gold v. El Salvador (Pac Rim Cayman LLC v. Republic of El Salvador), ICSID Case ARB/09/12.

International Court of Justice, Gabčlkovo-Nagymoros Case, separate opinion of Justice Weeramantry, ICJ Reports, 1997.

International Court of Justice, Legality of the threat or use of nuclear weapons, Advisory Opinion, ICJ Reports, 1996.

International Court of Justice, Territorial and maritime dispute (Nicaragua v Colombia), Judgment, ICJ Reports, 2012.

Petition 912/14 filed before the Inter-American Commission on Human Rights on 17 June 2014.

Republic of Colombia, "Request for an advisory opinion, presented by the Republic of Colombia, concerning the interpretation of article 1(1), 4(1) and 5(1) of the American Convention on Human Rights", 14 March 2016, in http://www.corteidh.or.cr/solicitudoc/solicitud_14_03_16_ing.pdf 